\title{
Organic Farming in the Nordic Countries - Animal Health and Production
}

\author{
By S. M. Thamsborg
}

Organic Animal Health and Production, Dept. of Animal Science and Animal Health, The Royal Veterinary and Agricultural University, Grønnegårdsvej 2, DK-1870 Frederiksberg C.

\begin{abstract}
Organic farming (or ecological agriculture) is of growing importance in the agricultural sector worldwide. In the Nordic countries, $1-10 \%$ of the arable land was in organic production in 1999. Organic farming can be seen as an approach to agriculture where the aim is to create integrated, humane, environmentally and economically sustainable agricultural production systems. Principles like nutrient recycling, prevention rather than treatment and the precautionary principle are included in aims and standards. Animal welfare is another hallmark of organic livestock production but despite this, several studies have indicated severe health problems e.g. in organic poultry production in Denmark. Also the quality of animal food products in relation to human health, particularly the risk of zoonotic infections, has been debated. For these reasons there is a need for improvement of production methods and animal health status. Vets play an important role in this development through work in clinical practice and in research. On-farm consultancy should be tailored to the individual farmers needs, and the practitioner should be willing to take up new ideas and when needed, to enter a critical dialogue in relation to animal welfare. Better base line data on animal health and food safety in organic food systems are needed.
\end{abstract}

Organic farming, animal health, animal welfare, food safety, diseases

\section{Introduction}

Organic farming (ecological agriculture or biological farming) is of growing importance in the agricultural sector of the Nordic countries. The reason for this being increasing production and market share of organic farm products. Organic farming is also to a large extent setting the scene in the public debate in areas like use of antibiotics in farm animals, alternative therapy, food safety and animal welfare and ethics. Another important aspect is the influence of organic standards on national legislation. As an example, several Danish organic standards preceded similar governmental legislation for the whole agricultural sector e.g. the ban on ruminant products in ruminant feed, animal housing and management according to physiological and ethological needs, and the ban on preventive use of antibiotics and anthelmintics.

As organic farming rely on product premiums in most countries, the market is very sensitive to consumers' perception of the production method and product quality. In a recent Danish survey of 1500 consumers' motives for buying organic products (phrased as an open question), own health, environmental considerations and animal welfare rated first, second and third (Suzanne Beckmann, upubl. data, 2000) thus confirming several earlier studies that organic products are perceived as healthier than conventional.

The question of quality of animal food products and the major focus on animal welfare (and 
thus animal health) in organic farming make it relevant today to consider the state of the art and to discuss future veterinary challenges in this production system. The purpose of the present paper is to provide a framework for understanding of aims and basic concepts in organic farming, to give a brief overview of the present state, including selected problem areas relevant to veterinarians and to briefly speculate on future trends. Although organic farming has to be viewed as a whole (soil, plants and animals), the focus will be on livestock in organic farming.

\section{Definitions}

\section{Aims in organic farming}

Organic farming can be seen as an approach to agriculture where the aim is to create integrated, humane, environmentally and economically sustainable production systems (Lampkin et al. 1999). It is a characteristic feature of organic farming that aims are formulated. These aims form background for the detailed standards or rules of practice. In 1989, organic movements in the Nordic countries agreed on the following rather broad description of organic farming:

Organic agriculture represents a self-supportive, well-balanced and sustainable agro-ecosystem. The system is based on the cyclical use of local and renewable resources as much as possible. Organic agriculture is based on a holistic view and includes the ecological, economical and social aspects of agricultural production in a local and global perspective. In organic agriculture, nature and the environment have their own value. Thus, humans have a moral responsibility to farm in a way that makes the cultural landscape an integrated and positive part of nature (translated from Kølster, 1989).

It is interesting that animal welfare was not mentioned specifically in the definition although it became a hallmark in relation to live- stock production. The principle aims are expressed more concisely in the standards document of International Federation of Organic Agriculture Movements (IFOAM), e.g.:

- to produce food of high quality in sufficient quantity

- to interact in a constructive and life-enhancing way with natural systems and cycles

- to encourage and enhance biological cycles within the farming system, involving microorganisms, soil flora and fauna, plants and animals

- to maintain and increase long-term fertility of soils

- to use, as far as possible, renewable resources in locally organised production systems

- to maintain the genetic diversity of the production system and its surroundings

- to create a harmonious balance between crop production and animal husbandry

- to give all livestock conditions of life with due consideration for the basic aspects of their innate behaviour (Anon. 1998)

\section{Basic concepts}

Three concepts fundamental to production in organic farming systems deserve further consideration, particularly in relation to livestock. Livestock plays an important role in nutrient recycling on the farm and contributes significantly towards the aim of operating as far as possible within a closed system. The closed cycle principle needs not necessarily apply at the individual farm but can apply at a regional level thus facilitating stockless farming. In organic farming, nitrogen self sufficiency is secured through the use of legumes and biological nitrogen fixation as well as effective recycling of organic materials, including crop residues and livestock manure (Lampkin, 1990). Maintaining and improving soil fertility through crop rotation, appropriate soil tillage, application of 
manure etc. are crucial to achieve this goal. Nitrogen is easily lost by leaching or volatilisation, and without careful management an organic system can contribute considerable amounts of nitrate to drainage water. A Danish study using a simple mathematical model for $\mathrm{N}$-leaching and nutrient budgets concluded that organic farms on sandy soils with either plant production or dairy cattle had markedly less risk of nitrate leaching compared to similar conventional farms (Hansen \& Kristensen, 1998). Conclusions regarding pig producing farms (sandy or clay soils) were less clear. Increased conversion to organic farming was advocated by the Bichel-commission in Denmark as one of the three best approaches to reduce the use of pesticides thereby improving environment (Anon. 1999a). A 100\% conversion (nonvoluntary) of Danish agricultural production was considered economically and politically unrealistic.

The concept of prevention rather than treatment is well known to most veterinarians. According to the present EU livestock regulation No. 1894/99, diseases in livestock in organic production are to be prevented by means of:

- selection of appropriate breeds and strains

- the application of animal husbandry practices appropriate to the requirements of each species, encouraging strong resistance to disease and the prevention of infections

- use of high quality feed, together with regular exercise and access to pasturage, having the effect of encouraging the natural immunological defence of the animal

- ensuring an appropriate density of stocking, thus avoiding overstocking and any resulting animal health problems (Anon. 1999b).

This does not preclude that animals sick or injured must be treated immediately, if necessary in isolation and in suitable housing. In order to provide further incentives to prevention, the withdrawal periods following medical treatment are extended. According to the EU livestock regulation No. 1894/99, a new conversion period (typically 3-6 months) is required if an individual animal with a production life longer than a year receives more than 3 courses of medical treatments within a 12 month period (Anon. 1999b). In my opinion these rules are not based on concern of food safety but rather a wish to minimize use of medicine and to promote means of disease prevention. It is also important to note that disease prevention through medication, formerly often used in conventional farming, is not compatible with organic practices. This may, however, create problems in certain areas e.g. ectoparasite control in extensively managed organic sheep (cf. Keatinge et al. 2000). In the USA., it is currently being proposed by the USDA that any antibiotic treatment will result in the animal losing its organic status permanently.

The precautionary principle has recently been declared a key tenet of risk management in e.g. protection of human, animal and plant health in EU (Gremmen \& Van den Belt, 2000). According to the commission, the principle covers those specific circumstances where scientific evidence is insufficient, inconclusive or uncertain and that there are indications through preliminary objective scientific evaluation that there are reasonable grounds for concerns for potentially dangerous effects on the environment, human, animal or plant health. In organic farming, a precautionary principle has for a long time formed part of the background for the ban on genetically modified organisms (GMOs), pesticides, certain types of embryotechnology, and use of hormonal regulation of production. In a wider perspective, organic farming as a whole can be seen as the precautionary principle applied to agricultural production. 


\section{Status in the Nordic countries \\ Historical background}

A small number of biodynamic farms established in the Nordic countries in the 1930-ties, later inspired the pioneers of organic farming in the 1970-ties. Increasing concern over environmental issues in intensive agriculture, in particular problems with the use of pesticides and commercial fertilizers, was the major driving force. Contributory factors were an increasing market for products perceived as healthy and concern for animal welfare. The development has thus been driven largely by consumer demand and visionary farmers and later supported by financial premiums or direct governmental subsidies (Table 1). Apart from NØLL formed in 1971, organic farmers organizations were formed in the 80-ties. Only in recent years has organic farming been supported by the research establishment with increasing numbers of $\mathrm{Ph}$. D. students in the 90-ties, and later by large, government funded research programmes in e.g. Sweden and Denmark in the mid 90-ties and professorial chairs at universities.

The philosophical background for organic farming has been explained as a blend of some kind of deep ecology, placing humans with ethical responsibilities towards the soil, the plants, the entire living nature, and a more utilitarian and anthropocentric approach where organic farming is seen as a means of solving manmade environmental problems (Kaltoft, 2000). The latter approach is, however, not anthropocentric in a strict sense as improved animal welfare is an important element. The utilitarian point of view is hold by government authorities, as expressed in most legislative rules, whereas the organic farming movements share a more deep ecology view point (Kaltoft, 2000). In the process of generating knowledge, the development can also be seen as a move from learning from farmers experiences to a more, traditional

Table 1. An overview of the institutional development of organic farming in the Nordic countries (modified from Lund, 2000)(Govt.: governmental)

\begin{tabular}{|c|c|c|c|c|c|}
\hline & Denmark & Finland & Iceland & Norway & Sweden \\
\hline $\begin{array}{l}\text { Organic farmers } \\
\text { organizations }\end{array}$ & $\begin{array}{l}1981 \text { Landsfor- } \\
\text { eningen økologisk } \\
\text { jordbrug (LØJ) }\end{array}$ & 1985 Luomuliitto & 1993 VOR & $\begin{array}{l}1971 \text { NØLL } \\
1987 \text { Økopro- } \\
\text { dusentarne }\end{array}$ & $\begin{array}{l}1985 \text { Alternativ- } \\
\text { odlarnas } \\
\text { riksförbund }\end{array}$ \\
\hline $\begin{array}{l}\text { National } \\
\text { standards for } \\
\text { organic farming }\end{array}$ & $\begin{array}{l}1981 \text { LØJ } \\
1987 \text { Govt. }\end{array}$ & $\begin{array}{l}1986 \\
1994 \text { Govt. }\end{array}$ & 1995 Gvt. & $\begin{array}{l}1986 \text { and } 1987 \\
1995 \text { Govt. } \\
\text { 'connected' }\end{array}$ & $\begin{array}{l}1985 \text { KRAV } \\
1995 \text { Govt. } \\
\text { 'connected' }\end{array}$ \\
\hline $\begin{array}{l}\text { Organic stan- } \\
\text { dards for animal } \\
\text { husbandry }\end{array}$ & $\begin{array}{l}1981 \text { LØJ } \\
1987 \text { Govt. }\end{array}$ & 1988 & 1995 Govt. & $\begin{array}{l}1989 \\
1995 \text { Govt. } \\
\text { 'connected' }\end{array}$ & 1987 \\
\hline $\begin{array}{l}\text { Govt. economic } \\
\text { support }\end{array}$ & $\begin{array}{l}\text { 1987: conversion } \\
1993\end{array}$ & 1990: conversion & 1999 & 1990 & 1989 \\
\hline $\begin{array}{l}\text { First dissertation: } \\
\text { plant production } \\
\text { animal product. }\end{array}$ & $\begin{array}{l}1985 \text { (Ph.D.) } \\
1995 \text { (Ph.D.) }\end{array}$ & 1998 & 1995 (B.Sc.) & 1993 & 1981 \\
\hline
\end{tabular}


Table 2. Number of organic farms and total area of organic production in Nordic countries at end of 1999 (source: SÖL 2000, http://www.organic-europe.net) and examples of typical subsidies in 1997 (source: Lampkin et al. 1999). In most countries permanent grassland is excluded from subsidies.

\begin{tabular}{|c|c|c|c|c|c|}
\hline & Denmark & Finland & Iceland & Norway & Sweden** \\
\hline No. organic farms & 3009 & 5197 & 33 & 1745 & 3252 \\
\hline As $\%$ of all farms & $4.0^{*}$ & 6.1 & 0.8 & $2.6^{*}$ & 3.8 \\
\hline Total organic area (ha) & 146686 & $137000^{*}$ & 2500 & 18773 & 155463 \\
\hline As $\%$ of total area & 5.5 & 6.3 & 0.6 & $1.8^{*}$ & 5.5 \\
\hline $\begin{array}{l}\text { Government support (ECU/ha/year): } \\
\text { cereals/arable crops }\end{array}$ & 114 & $162-312$ & n. a. & 187 & $104 / 185$ \\
\hline grass/forage & 60 & $264-414$ & n. a. & 137 & $173 / 254$ \\
\hline
\end{tabular}

* estimate

** only KRAV-certified farms. These farms together with organic farming supported under Council Regulation (EU) 2078/92 cover almost $10 \%$ of arable land in Sweden.

expert knowledge based system e..g. the outcome of government funded research programmes.

\section{Brief statistics}

Relatively few farms were certified organic before early 80 -ties. With the introduction of governmental subsidies in the late 80 -ties/early 90 ties in most Nordic countries, more farms converted. An EU-regulation in 1992 provided a framework for all EU member states to implement policies to support organic farming. The scheme was implemented in Denmark in 1994 resulting in higher subsidies and an almost exponential increase in number of farms converting. The scheme was implemented in Finland and Sweden in 1995 when they joined EU and both countries are now having a large organic agricultural production (Table 2). Organic livestock production is also influenced by the market. As an example, the premiums for organic milk in Denmark have decreased recently, and in 2000 less than 10 dairy herds started conversion compared to about 200 in 1999.

\subsection{Standards}

National standards for organic animal husbandry have been in effect in most Nordic countries since mid 1980ties (Table 1) and will be covered by the next lecturer. The many yes/no requirements in the standards are easy to practice and is perhaps one of the reasons for the success of organic farming: a clear concept which is simple to communicate. However, there is a trend of standards becoming more and more detailed, particularly in relation to animal housing and management. This may be seen as an obstacle to the continuing development of organic farming. A most recent development is the EU-legislation, only relevant to Sweden, Finland and Denmark of course. The first EUdirective (Anon. 1999b) specifying socalled minimum standards for organic livestock production took in effect August this year (2000) and is presently being implemented in the national standards.

\section{Veterinary challenges}

Veterinary consultancy

Veterinarians play an important role in developing organic farming through work in clinical 
practice, as farm consultants, and in research. In Denmark, the involvement of veterinary practitioners in support and decision making on organic farms has been limited during the 90ties. With the growing number of farms, this situation is gradually changing and a dialogue is now been established with organic farmers/organisations regarding e.g. revision of standards, development of herd health programmes and possibilities for use of alternative medicine. Organic farmers expect practitioners and farm consultants to have some understanding of aims in organic farming and knowledge of standards, particularly changes in standards. Furthermore, the advice should be tailored to the individual farmer's needs, and the practitioner should be willing to take up new ideas. On the other hand, the veterinary practitioner should be critical, particular in relation to animal welfare. Organic farms represent a good opportunity to carry out preventive medicine.

\section{Research tasks}

An important task for veterinary researchers in organic farming is to provide documentation of production and base line data on health and disease. Much data has been presented at meetings, in internal reports or in the local farming press but the access for outside researchers has been limited. However, there is a growing awareness of this problem and in association with the large scale research programmes and education of researchers in this field, more studies will be published internationally. Examples of Nordic base line studies include a Swedish survey of lesions recorded at abattoirs in 1997 in organic and conventional animals (Hansson et al. 1999), studies on mastitis and somatic cell counts in organic dairy cattle in Denmark (e.g. Vaarst \& Enevoldsen, 1997) and a long list of published recordings from case-studies on organic farms (e.g. Strøm \& Olesen, 1997; Kristensen 1997 \&1998; Mogensen et al. 1999).
Important base line data to be obtained include:

- risk assessment in organic pig production regarding food safety, particularly zoonotic agent like Salmonella, Campylobacter, parasites etc.

- use of antibiotics in pig and cattle enterprises and implications for development of antibiotic resistance

- profiling of nutritional quality of organic products for human consumption

Detailed data on many of these aspects will be provided in later sessions. Improved recording systems and recording of production method (e.g. organic or out-door conventional) in central databases are highly warranted and will facilitate future base line studies.

It is important alongside documentation of health on-farm to initiate basic research relevant to organic farming. Innovative research performed in universities and other research institutions may offer support to the continuing development of organic farming. It is often reductionistic and runs a high risk of becoming detached from the principles of organic farming. It is thus important to link this research to experiences of organic practitioners at some stage of the process.

An example of basic research leading to recognition of new biological relationships relevant and perhaps very important to organic farming is the effect of diet constituents and structure on bacterial and nematode infections in pigs. Several Danish studies have indicated that commercial feed triple the risk of establishment of Salmonella infections in individual pigs compared to home-grown feed (cf. Dahl, 1997). Home-grown feed is in contrast to commercial feed not heat-treated, have a coarser structure after grinding and is not pelletted. It improves the condition of the gastrointestinal tract (e.g. less lesions in the stomach) and results in different fermentation pattern in the large intes- 
tine, but the production economy is generally affected negatively (Jørgensen et al. 1999). In organic farms, pigs receive a high proportion of home produced feed, and roughage (fresh grass or whole grain silage ad libitum) should be available at all times in all age groups. Although the influence of roughage per se on Salmonella infections has not been investigated, the feeding regime on organic farms is likely to decrease the risk of salmonellosis and perhaps counteract the potentially higher risk associated with a continuous production system and access to the outdoor. In contrast, high levels of insoluble dietary fibres and a non-pelleted diet have resulted in higher establishment rates and increased fecundity of the intestinal nematode Oesophagostomum dentatum compared to pelleted diets or diets of similar protein and energy levels but rich in digestible carbohydrates (Petkevicius et al., 1995 and 1998). Ascaris-infections were not affected in a similar way. These findings implicate that not only the high exposition outdoors but also the feeding regime, may affect the establishment of helminth infections in organic pig production systems. Also interactions between pathogens may be affected.

In summary, these studies clearly show that it may be difficult to predict the outcome at farm level when new pratices are introduced, or old practices re-adopted, in the organic standards. Access to roughage and out-door conditions in pig production may thus have wide implications for the epidemiology of different infections, behaviour, environment, economy and perhaps food safety. Basic research may play a significant role in the building of knowledge and understanding of the systems.

Other tasks where basic research is needed include methodology in welfare assessment (particularly welfare implications of subclinical disease), climatic and behavioural effects of new and near-natural housing conditions, meth- ods for scientifical assessment of the effects of alternative medication e.g. herbal remedies and homoeopathy, relationships between welfare, immunity and disease resistance and the use of more holistic methods to assess food quality.

\section{Future trends}

In the last decade organic farming has become institutionalized (Kaltoft, 2000). From being a small grass-root movement in opposition to the established agricultural food industry, organic farming is now part of the 'establishment' with large production units, retail from supermarkets, a considerable market share and not least, substantial government funded research in several Nordic countries. From being able to market products solely by being alternative to conventional farming with its perceived environmental and animal welfare problems, the burden of proof now lies with the organic producers. Although this represents an oversimplification, it is a fact in Denmark for instance, that critical questions are now being raised by consumers, politicians, researchers and others: is organic produce healthier for humans considering both nutritional qualities and zoonotic aspects? is the level of animal welfare acceptable on organic farms? is it better to buy national/1ocal conventional products than imported, organic products with a high energy expenditure for transportation etc. Consumers obviously focus on single issues and do not realize/debate the benefits of organic farming in a larger perspective. However, the concern of consumers and the critique from others should be recognized as an important factor in future development. More information is needed from the organic farming organizations (and researchers) to influence and re-direct the discussion, and the need for development of production methods and scientific documentation of product quality and animal welfare are further emphasized. 


\section{Acknowledgments}

I wish to thank Erik S. Jensen and Torben W. Bennedsgaard for their comments on the manuscript and The Hede Nielsen Foundation for financial support.

\section{Referencer}

Anonymous: Basic standards for organic production and processing, IFOAM, 1998, $57 \mathrm{pp}$.

Anonymous: Udvalget til vurdering af de samlede konsekvenser af en afvikling af pesticidanvendelsen (Bicheludvalget) - rapport fra hovedudvalget, 1999a, $144 \mathrm{pp}$.

Anonymous: EU Regulation no. 1804/1999: Production of organic livestock (supplementing EU Regulation 2092/91), 1999b.

Dahl J: Foderrelaterede risikofaktorer for subklinisk salmonellainfektion. Veterinærinformation, 1997, no. 6 .

Gremmen B, Van den Belt H: The precautionary principle, or the unbearable lightness of the burden of proof. Proc. $2^{\text {nd }}$ Congress EurSafe (Eds. Robinson), Copenhagen, 2000, pp. 125-128.

Hansen B, Kristensen ES: N-udvaksning og -balancer ved omlægning fra konventionelt til økologisk jordbrug. In: Kvælstofudvaskning og -balancer i konventionelle og økologiske produktionssystesmer (Eds. Kristensen \& Olesen), 1998, FØJO-report.

Hansson I, Hamilton C, Forslund K, Ekman T: En jämförelse av slaktresultat mellem KRAVuppfödda och konventionellt uppfödda djur. In: Ekologisk djurproduktion enligt KRAV (Eds. Hammarberg \& Beck-Friis), Supplementum 29, Svensk Veterinär tidning, 1999, 51(2), 17-24.

Jørgensen L, Dahl J, Jensen BB, Poulsen HD: Effekt af ekspandering, pelletering og formalingsgrad på Salmonella, produktionsresultater og mavetarmsundhed hos slagtesvin samt på fytaseaktivitet og vitaminstabilitet i foder. Info-svin, Danske Slagterier, Rapport no. 426, 1999, 24 pp.

Kaltoft $P$ : What is the ethical foundation of organic farming in a reflexive modern society. Proc. $2^{\text {nd }}$ Congress EurSafe (Eds. Robinson), Copenhagen, 2000, pp. 165-168.

Keatinge R, Gray D, Thamsborg SM, Martini A, Plate $P$ : EU-regulation 1804/1999 - the implications of limiting allopathic treatment. In: Diversity of livestock systems and definition of animal welfare. Proc. $2^{\text {nd }}$ workshop of the Network of Animal Health and Welfare in Organic Agriculture (NAHWOA), 2000, pp. 92-98.
Kristensen T: Studier i økologiske jordbrugssystemer. Beretning fra Statens Husdyrbrugsforsøg, no. $734,1997,159$ pp.

Kristensen T: Studier i økologiske jordbrugssystemer, DJF-rapport nr. 1, Husdyrbrug, 1998, 178 pp.

Kølster P: Økologisk jordbrug - fælles nordisk beskrivelse. In: Ecological agriculture in the Nordic countries. Report of 1989 meeting of Nordic researchers and advisors in ecological agriculture and Nordic IFOAM, 1989, KVL, København.

Mogensen L, Kristensen T, Kristensen IS: Økologisk mælkeproduktion. Teknisk-økonomisk gårdresultater 1997-98. Typetal for økologisk mælkeproduktion. DJF-Rapport nr. 10, Husdyrbrug, 1999, $138 \mathrm{pp}$.

Lampkin N: Organic Farming. Farming Press, 1990, $715 \mathrm{pp}$.

Lampkin N, Foster C, Padel S, Midmore P: The policy and regulatory environment for organic farming in Europe. Vol. 1, Hohenheim Univ., 1999, $166 \mathrm{pp}$.

Lund V: What is ecological animal husbandry? In: Ecological animal husbandry in the Nordic countries. Proc. NJF-seminar No. 3030 (Eds. Hermansen, Lund \& Thuen), 2000, 9-12.

Petkevicius S, Nansen P, Knudsen KEB, Skjøth F: The effect of increasing levels of insoluble dietary fibre on the establishment and persistence of Oesophagostomum dentatum in pigs. Parasite, 1998, 6, 17-26.

Petkevicius S, Bjørn H, Roepstorff A, Nansen P, Knudsen KEB, Barnes EH, Jensen K: The effect of two types of diet on populations of Ascaris suum and Oesophagostomum dentatum in experimentally infected pigs. Parasitology, 1995, 11, 395-402.

Strømm T, Olesen I: Mjølkekvalitet, helse og holdbarhet på kyrne ved omlegging til økologisk mjølkeproduktion, Rapport Norsøk, 1997, 77 pp.

Vaarst M, Enevoldsen C: Patterns of clinical mastitis manifestations in Danish organic dairy herds. Journal of Dairy Science, 1997, 64, 23-37. 


\section{Sammendrag}

Økologisk jordbrug har stigende betydning i landbrugssektoren i store dele af verden. I de nordiske lande blev 1-10\% af landbrugsjorden dyrket økologisk i 1999. Økologisk jordbrug kan betragtes som en integreret, miljømæssig og økonomisk bæredygtig tilgang til landbrugsproduktion. Målsætninger og regler bygger på principper om bl.a. lukkede næringstofskredsløb, forebyggelse fremfor behandling og forsigtighedsprincippet. Dyrevelfærd udgør et væsentligt element i målsætningen, men på trods heraf er der beskrevet alvorlige sygdomsproblemer i $ø$ kologisk produktion, eksempelvis høj dødelighed i danske fjerkræbesætninger. Kvaliteten af de økologi- ske produkter med hensyn til human sundhed, herunder risikoen for levnedsmiddelbårne infektioner, er også til debat. På denne baggrund er der behov for udvikling af egnede produktionsmetoder og forbedret dyresundhed. Både praktiserende dyrlæger og forskere kan bidrage til denne udvikling. Sundhedsrådgivning på besætningsniveau er af væsentlig betydning, men dyrlægen bør også være parat til at tage nye udfordringer op i relation til den økologiske produktion og om nødvendigt, indgå i en kritisk dialog omkring dyrevelfærd. Det er samtidig påkrævet, at der opsamles basale data om sygdomsforekomst og fødevaresikkerhed i den økologiske animalske produktion. 